\title{
Analisa Pembebanan pada Railing Overhead Conveyor untuk Kandang Ayam Broiler Tipe Closed House
}

\author{
Munadi $^{1^{*}}$, Ismoyo Haryanto ${ }^{2}$, Gafar Maulana ${ }^{3}$ \\ 1,2,3Departemen Teknik Mesin, Fakultas Teknik, Universitas Diponegoro \\ Jl. Prof. Soedarto, S.H., Tembalang, Semarang, Jawa Tengah 50275 \\ * Penulis korespondensi; E-mail: munadi@ft.undip.ac.id
}

\begin{abstract}
ABSTRAK
Terdapat dua proses pemindahan barang dalam peternakan ayam broiler yang masih menggunakan metode konvensional, yaitu pada proses pengangkutan sekam dan penjarangan (pemanenan) ayam broiler. Pada usaha beternak ayam broiler, diperlukan efisiensi waktu dan tenaga dengan tidak mengurangi kualitas ayam broiler yang dihasilkan. Salah satu usaha efisiensi adalah mengurangi ongkos pemindahan barang dalam pada kandang closed house adalah dengan membuat overhead conveyor. Overhead conveyor dirancang untuk mengurangi waktu persiapan kandang ayam broiler diisi DOC (day old chicken) maupun saat panen. Analisa pembebanan atas desain railing overhead conveyor dilakukan untuk mengetahui faktor keamanan (safety factor). Analisa pembebanan dilakukan melalui pendekatan dua model yaitu railing lurus $1 \mathrm{~m}$ dan railing belok dengan kurvatur 0,6 m. Berdasarkan hasil analisa pembebanan, nilai faktor keamanan pada railing overhead conveyor lurus $1 \mathrm{~m}$ sebesar 2,3; sedangkan railing belok dengan kurvatur 0,6 m sebesar 2,45. Berdasarkan nilai tersebut, maka desain dinyatakan aman untuk dibuat prototipe.
\end{abstract}

Kata kunci: Ayam broiler; closed house; overhead conveyor; faktor keamanan.

\begin{abstract}
There are two processes of moving goods in broiler chicken farms that still use conventional methods, namely in the process of transporting husks and thinning (harvesting) broilers. In the business of raising broiler chickens, time and energy efficiency is needed without reducing the quality of the broiler chickens produced. One of the efficiency efforts is to reduce the cost of moving goods inside closed house cages by making an overhead conveyor. The overhead conveyor is designed to reduce the preparation time for broiler chicken coops to be filled with DOC (day old chicken) and at harvest time. The load analysis on the overhead conveyor railing design is carried out to determine the safety factor. The loading analysis is carried out through a two-model approach, namely $1 \mathrm{~m}$ straight railing and turning railing with $0.6 \mathrm{~m}$ curvature. Based on the results of loading analysis, the value of the safety factor on a straight $1 \mathrm{~m}$ overhead conveyor railing is 2.3; while railing turns with a curvature of $0.6 \mathrm{~m}$ at 2.45. Based on this value, the design is declared safe for prototyping.
\end{abstract}

Keywords: Broiler chicken; closed house; overhead conveyor; safety factor.

\section{PENDAHULUAN}

Perkembangan teknologi sangat pesat di semua aspek, seperti kesehatan, pendidikan, keamanan, dan terutama pada ilmu rekayasa teknik. Banyak alat yang dirancang untuk dapat membantu pekerjaan manusia. Demikian juga pada usaha beternak ayam broiler, dimana diperlukannya efisiensi waktu dan tenaga yang baik untuk dapat menghasilkan ayam broiler dengan kualitas baik. Selain itu juga harus efiensi terkait biaya operasional, diantaranya dalam penurunan biaya pengangkutan dan pemindah- an barang kebutuhan beternak ayam broiler [1]. Salah satu usaha mengurangi biaya pemindahan barang dalam beternak ayam broiler pada kandang closed house adalah dengan membuat conveyor. Conveyor adalah suatu sistem mekanik yang mempunyai fungsi memindahkan barang [2]. Conveyor juga didefinisikan sebagai suatu alat bantu yang digunakan untuk mengangkut suatu material dari suatu tempat ke tempat lain secara terus menerus [3]. Conveyor banyak dipakai di industri dimana difungsikan untuk transportasi barang yang jumlahnya sangat banyak dan berkelanjutan [4]. Conveyor 
sangat multifungsi dalam membantu meminimalisir waktu dan tenaga yang dibutuhkan untuk keperluan dalam kendang ayam broiler jenis closed house.

Terdapat dua proses pemindahan barang dalam beternak ayam broiler yang masih menggunakan metode konvensional, yaitu pada proses penjarangan dan pemanenan ayam broiler, serta proses pengangkutan sekam padi untuk litter kandang ayam broiler. Penjarangan adalah suatu tindakan pengurangan jumlah ayam broiler dengan cara melakukan pemanenan pada ayam berumur 21-28 hari [5]. Penjarangan ini dilakukan dengan tujuan agar berat ayam dapat meningkat dikarenakan zat amoniak yang tidak berlebih, dan efisiensi penggunaan lahan kandang. Ayam hasil penjarangan ini langsung dijual ke pelanggan. Sedangkan sekam padi merupakan salah satu bahan yang digunakan untuk alas atau litter kandang ayam [6]. Sebagian besar peternak ayam atau unggas di Indonesia menggunakan bahan ini karena mudah didapat dan harganya paling murah diantara yang lain. Selain itu, sekam padi paling banyak digunakan untuk alas kandang karena mempunyai sifat-sifat sebagai berikut, antara lain dapat menyerap air baik, bebas debu, kering, mempunyai kepadatan (density) yang baik, dan mamberi kehatan kandang [7]. Litter kandang digunakan pada awal pemeliharaan ayam dari umur DOC (days old chicken) sampai umur 14 hari.

Conveying equipment terdiri dari beberapa macam peralatan pemindah, dimana dalam pemilihan conveyor atau peralatan pemindah lainnya dipengaruhi oleh jenis material yang akan diangkut, kapasitas yang dibutuhkan dalam waktu tertentu, arah dan panjang pemindahan, sehingga selain faktor engineering, faktor nilai ekonomis juga perlu diperhatikan dalam pemilihan peralatan pemindah material [8]. Sistem conveyor overhead klasik biasanya terdiri dari sistem transportasi overhead yang terikat ke rel dengan kendaraan yang dapat dikontrol secara individual, keseluruhannya bersatu sebagai sistem aliran material yang kompleks [9]. Pada dasarnya mechanical conveyor merupakan alat untuk mengangkut beban secara terus menerus atau continue, baik berupa curah (bulk) maupun bentuk satuan (unit) [10]. Sebuah unit conveyor dirancang untuk menangani potongan-potongan kecil dalam wadah dengan berat dari beberapa ons hingga unit besar seperti filled pallets, crates, atau rakitan dengan berat berton-ton [11]. Ada beberapa jenis conveyor antara lain belt conveyor, overhead conveyor (monorail), screw conveyor, dan roller conveyor [12]. Dari berbagai jenis conveyor dan fungsinya yang beragam terdapat banyak jenis yang dapat berguna untuk proses pengangkutan sekam dan pemanenan ayam broiler, jenis overhead conveyor dipilih karena sistem kerja overhead conveyor berada di atas kepala atau di atap, sehingga tidak memakan lahan kendang untuk memaksimalkan jumlah ternak ayam broiler [13].
Pengangkutan pada kedua proses ini pada saat ini mayoritas masih menggunakan tenaga angkut tenaga manusia, sehingga tidak ergonomis dan tidak efisien dalam industri ternak ayam broiler. Oleh karena itu, direncanakan model overhead conveyor untuk kandang ayam broiler closed house berdasarkan pertimbangan bahwa dengan dipoerasikannya alat ini merupakan salah satu cara meningkatkan produktifitas dan efisiensi tenaga kerja dalam beternak ayam broiler. Pada kandang ayam broiler model closed house akan dirancang menggunakan overhead conveyor sebagai material handling untuk mempercepat pengangkutan sekam dan akan sangat membantu pada saat pemanenan/penjarangan [14]. Sistem pengangkutan menggunakan conveyor sebagai material handling, dan HMI sebagai interface antara operator dengan sistem hardware akan memudahkan operator dalam mengoperasikan alat [15]. Pada penelitian ini, dimensi overhead coveyor yang dirancang memiliki dimensi $24 \mathrm{~m} \mathrm{x} 6 \mathrm{~m}$ dan digunakan pada kandang dengan dimensi $30 \mathrm{~m}$ x 12 $\mathrm{m}$.

\section{METODE PENELITIAN}

\section{Perancangan Komponen Overhead Conveyor}

Perancangan komponen overhead conveyor meliputi perancangan komponen railing, chain link, hook, serta sistem konfigurasi motor penggerak. Desain ini dibuat menggunakan software Solidworks 2017. Gambar 1 (a) menunjukkan salah satu desain kandang ayam broiler model closed house, sedangkan keseluruhan desain overhead conveyor pada kandang ayam broiler model closed house ditunjukkan pada Gambar 1 (b).

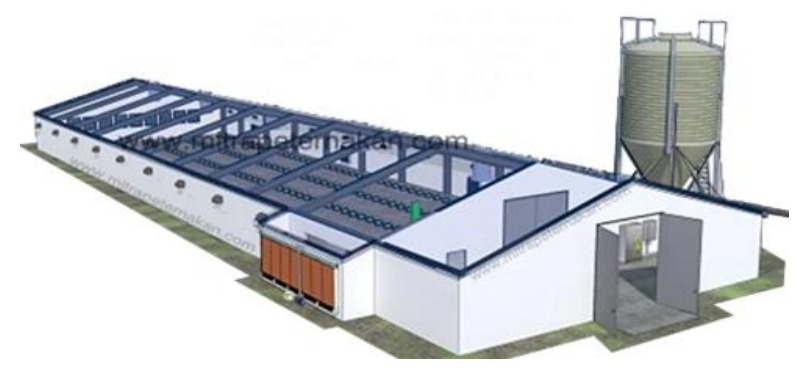

(a)

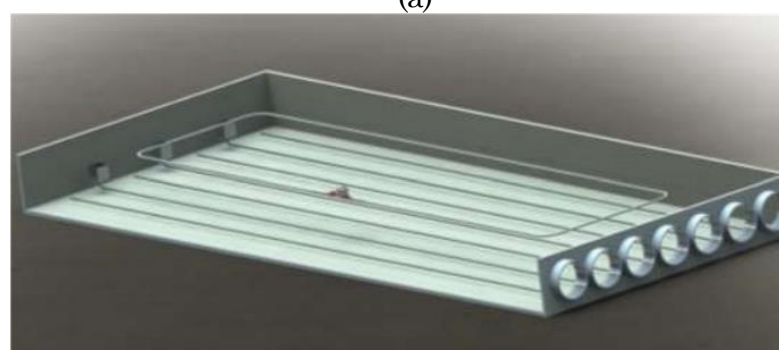

(b)

Gambar 1. Assembly overhead conveyor

\section{Railing}

Railing merupakan bagian utama dalam percancangan overhead conveyor dimana railing 
berfungsi sebagai jalan utama untuk proses aliran conveyor. Oleh karena itu, perancangan railing dibuat sesederhana mungkin dan sesuai dengan aspek kekuatan (dengan pertimbangan bahan yang akan dibawa), aspek keakuratan dimensi, aspek fungsional, dan aspek ekonomis. Kemudian dalam proses merancang railing, berdasarkan luas area yang telah ditentukan maka jalur overhead conveyor yang didesain disesuaikan dengan bentuk kandang ayam broiler closed house seperti pada Gambar 2 .

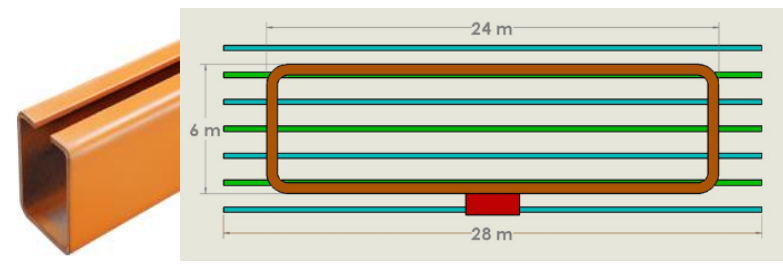

Gambar 2. Jalur railing overhead conveyor.

Keterangan:

Enclosed railing.
Jalur minum ayam broiler.
Jalur pakan ayam broiler.
Drive unit.

Pada Gambar 2 tersebut dapat dilihat bahwa total area overhead conveyor sebesar $24 \mathrm{~m} \mathrm{x} 6 \mathrm{~m}$ sudah dapat mencakup 4 jalur minum dan 3 jalur pakan ayam broiler, dimana panjang total railing adalah $60 \mathrm{~m}$. Sedangkan untuk pemilihan bentuk railing pada overhead conveyor didasarkan pemberian bobot beberapa parameter yang ditunjukkan Tabel 1.

Tabel 1. Pemilihan railing

\begin{tabular}{lcccc}
\hline Parameter & $\begin{array}{c}\text { Inside } \\
\text { Railing } \\
\text { Tube }\end{array}$ & $\begin{array}{c}\text { Outside } \\
\text { Railing } \\
\text { Tube }\end{array}$ & $\begin{array}{c}\text { Enclosed } \\
\text { Railing }\end{array}$ & IProfil \\
\hline Daya Angkut & 1 & 2 & 3 & 4 \\
Biaya & 2 & 3 & 4 & 1 \\
Pembuatan & & & & \\
Perawatan & 1 & 2 & 3 & 4 \\
Daya Tahan & 1 & 2 & 3 & 4 \\
Keamanan & 3 & 2 & 4 & 1 \\
Total & 8 & 11 & 17 & 14 \\
\hline
\end{tabular}

Pembobotan didasarkan pada tipe railing yang akan dipilih. Berdasarkan nilai pembobotan, maka didapatkan tipe railing yang dipakai untuk perancangan overhead conveyor untuk kandang ayam closed house adalah enclosed track railing. Hal ini ditinjau dari kelebihan dari segi biaya pembuatan, keamanan, dan perawatan. Sebelum proses perancangan, bahan material yang ada di pasaran ditinjau dan mencari bahan yang mudah ditemui, hal ini berfungsi agar proses produksi dapat dilakukan dengan mudah. Dengan hasil penentuan tipe railing yang diinginkan, dilanjutkan proses desain yang hasilnya ditunjukkan pada Gambar 3.

\section{Simulasi Pembebanan Railing Overhead Conveyor}

Tahap berikutnya adalah analisa pembebanan melalui simulasi pada software atas desain railing overhead conveyor. Simulasi komponen overhead conveyor terdiri dari komponen railing dan chain link. Distribusi beban pada railing akan disimulasikan dengan panjang railing $1 \mathrm{~m}$ pada model railing lurus dan railing belok dengan kurvatur 0,6 m. Simulasi distribusi beban dilakukan dengan pendekatan kondisi aktual yaitu dengan pembebanan dari pemanenan ayam broiler dimana massanya diasumsikan paling besar dibandingkan dengan pengangkutan sekam padi. Sebelum melakukan simulasi distribusi beban, terlebih dahulu mencari data beban aktual beruba beban distribusi merata dari deretan chain dan beban ayam broiler. Hal ini terkait dengan lebar carrier yang membawa ayam broiler saat penyiangan atapun saat panen. Sebagai contohnya carrier yang menampung berat 28 $\mathrm{kg} /$ carrier yang artinya setiap $1 \mathrm{~m}$ terdapat 1 carrier dengan panjang alas carrier adalah $1 \mathrm{~m}$, terdapat beban sebesar $28 \mathrm{~kg}$ lalu ditambahkan beban kurang lebih 5 set chain link adalah sebesar $4.2 \mathrm{~kg} /$ meter. Adapun diagram benda bebas (DBB) sederhana dapat dimodelkan sebuah batang horizontal yang mendapat beban distribusi merata sebesar $32.2 \mathrm{~kg}$ dan ditunjukkan pada Gambar 4.

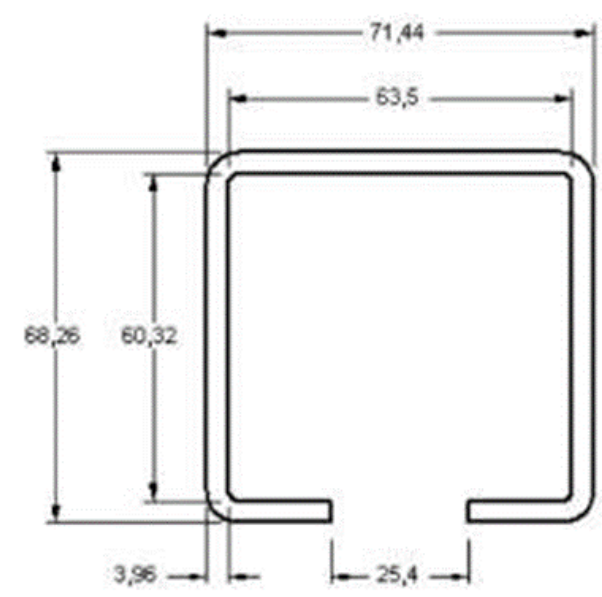

Gambar 3. Penampang railing
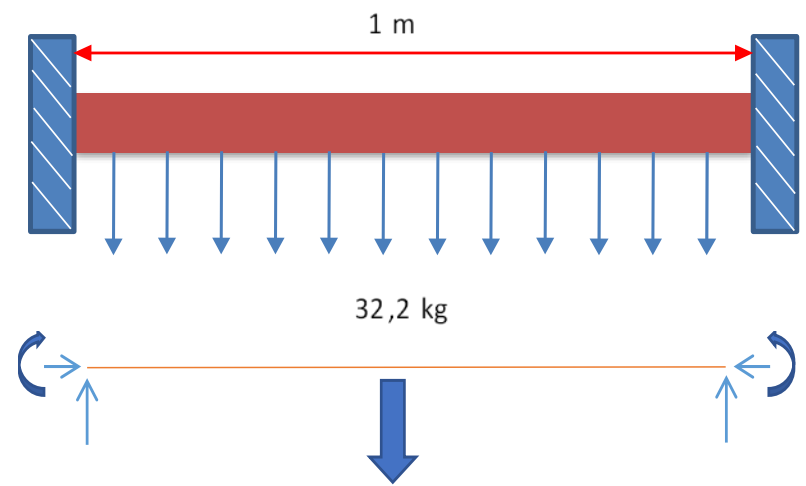

Gambar 4. DBB batang railing $1 \mathrm{~m}$. 
Berdasarkan DBB terkait beban dan tumpuannya, tahap selanjutnya yaitu analisa statis. Langkah pertama pada software adalah membuka file komponen desain railing. Kemudian klik tab simulation lalu klik panah pada tab study advisor dan pilih new study, sehingga akan menuju pilihan simulasi yang akan dijalankan seperti ditunjukkan hasilnya pada Gambar 5.

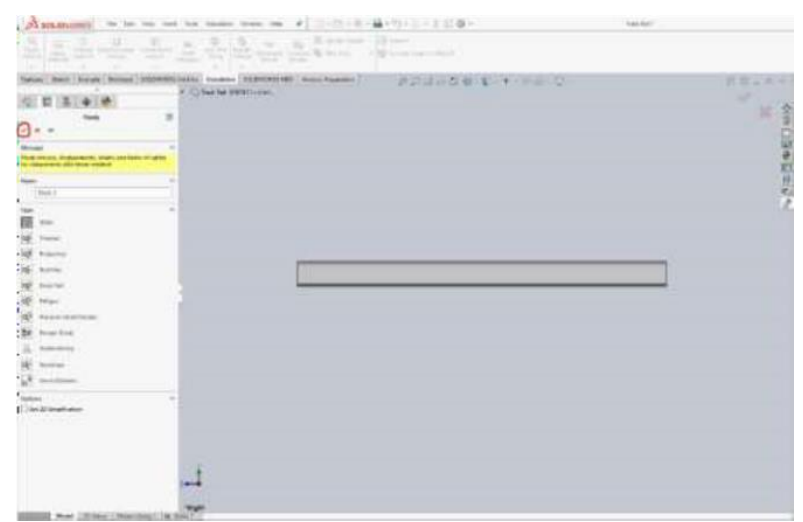

Gambar 5. Pilihan simulasi

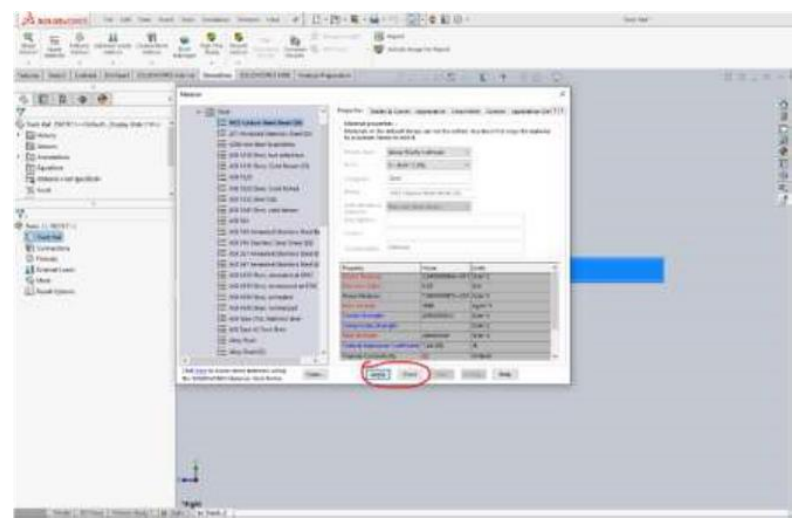

Gambar 6. Pilihan material

Setelah memilih simulasi pembebanannya static, maka selanjutnya klik centang dan lanjut ke langkah berikutnya, yaitu memilih material yang menjadi baham railing. Material yang digunakan adalah 1023 steel carbon sheet dengan yield strength sebesar $282 \mathrm{MPa}$. Berikutnya memilih menu apply dan close seperti yang ditunjukkan pada Gambar 6 . Langkah berikutnya adalah adalah menentukan tumpuan pada ujung railing. Pendekatan aktual digunakan dengan menentukan tumpuan fixed geometery pada setiap ujung batang railing dengan mengklik kanan pada fixtures, dan dipilih fixed geometry seperti ditunjukkan pada Gambar 7 .

Setelah menentukan jenis tumpuannya, maka langkah berikutnya adalah menentukan letak tumpuan seperti yang ditunjukkan pada Gambar 8 . Langkah berikutnya adalah menentukan gaya yang terjadi pada batang railing. Beban yang terjadi pada batang railing ini berupa beban terdistribusi merata dari deretan chain dan carrier yang menangkut beban paling besar yaitu ayam broiler dengan total beratnya adalah $32,2 \mathrm{~kg}$ dikalikan $9.81 \mathrm{~m} / \mathrm{s}^{2}$ sebesar $315,88 \mathrm{~N}$ dengan arah sumbu y bawah. Pemberian gaya beban diletakkan pada permukaan railing bagian dalam dimana permukaan tersebut berkontak langsung dengan roda chain. Penentuan letak gaya pada batang railing ditunjukkan pada Gambar 9.

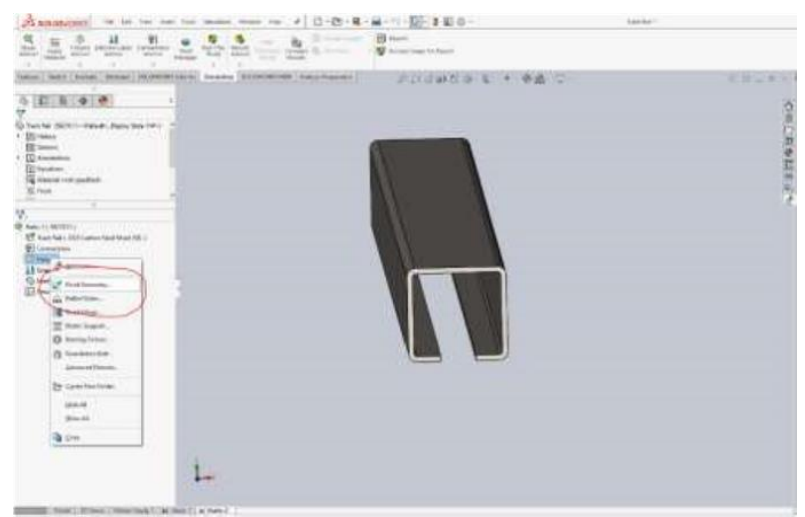

Gambar 7. Penentuan jenis tumpuan

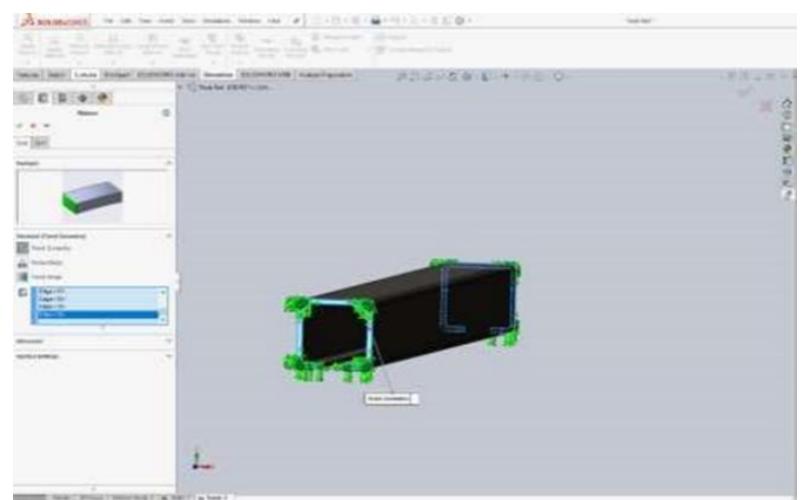

Gambar 8. Penentuan letak tumpuan

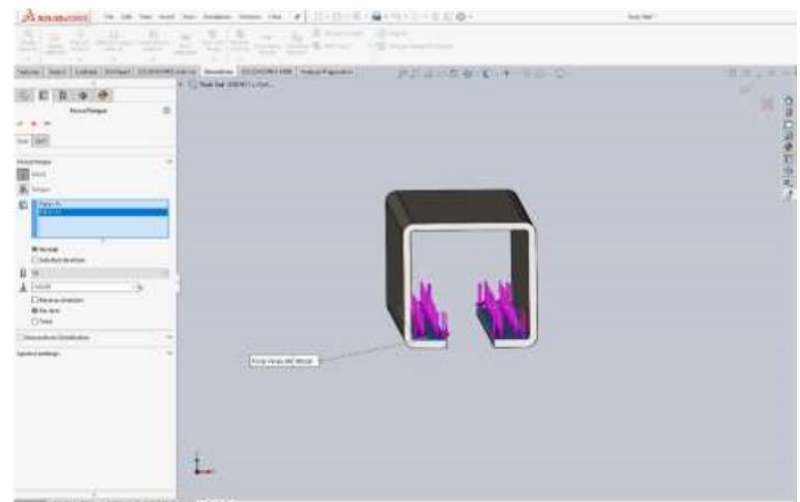

Gambar 9. Penentuan letak gaya pada batang railing.

Berikutnya adalah proses meshing atau memberikan mesh pada batang railing. Ketelitian pemberian mesh ini cukup penting. Berdasarkan proses meshing tersebut didapatkan jumlah elemen sebanyak 30.033 dan nodes sebanyak 60.438 . Untuk pengaturan menggunakan ukuran elemen rata-rata yang lebih kecil maka akan menghasilkan mesh yang lebih rapat, jumlah elemen dan nodes semakin banyak sehingga butuh waktu simulasi yang lama. Hasil proses meshing ditunjukkan pada Gambar 10. 
Langkah selanjutnya adalah simulasi batang railing dengan memilih tab run this study seperti yang ditunjukkan gambar lingkar merah pada Gambar 11.

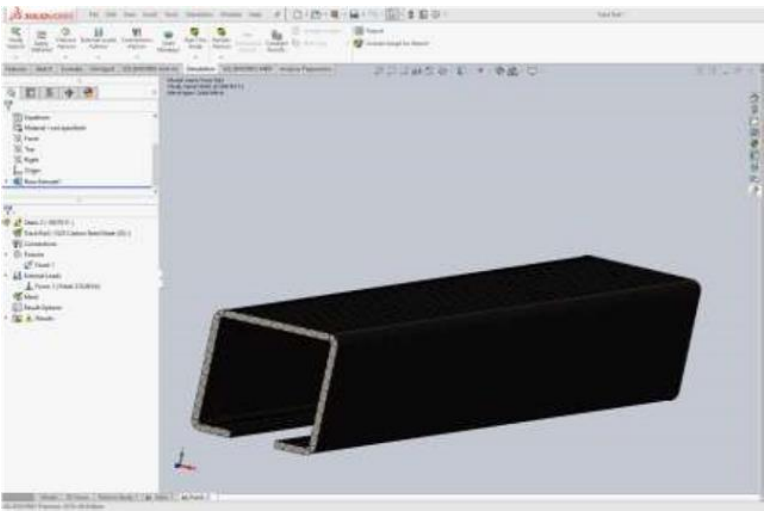

Gambar 10. Meshing pada batang railing

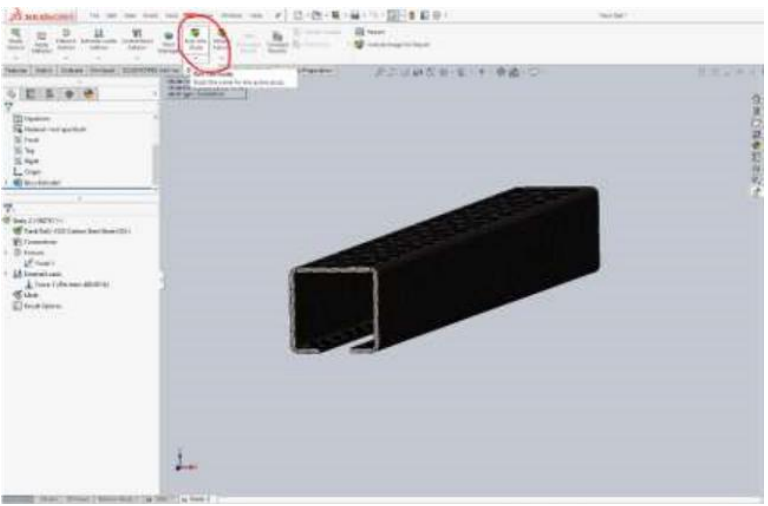

Gambar 11. Menjalankan simulasi

Simulasi statis juga dilakukan pada komponen railing dengan kurvatur 0,6 metersebagai model sample railing pada belokan. Railing berfungsi sebagai jalur belok dari overhead conveyor. Material yang digunakan pada railing ini sama dengan railing lurus $1 \mathrm{~m}$ yaitu 1023 steel carbon sheet dimana memeiliki nilai yield strength sebesar 282 $\mathrm{MPa}$. Railing dengan kurvatur 0,6 m ditunjukkan pada Gambar 12. Simulasi dilakukan secara aktual dimana total beban berasal dari chain dan carrier yang membawa ayam broiler sebesar $31,36 \mathrm{~kg}$ dikalikan $9,81 \mathrm{~m} / \mathrm{s}^{2}$ yaitu $307,64 \mathrm{~N}$. Tumpuan yang dipakai sama dengan pada simulasi railing $1 \mathrm{~m}$, yaitu tumpuan jepit.

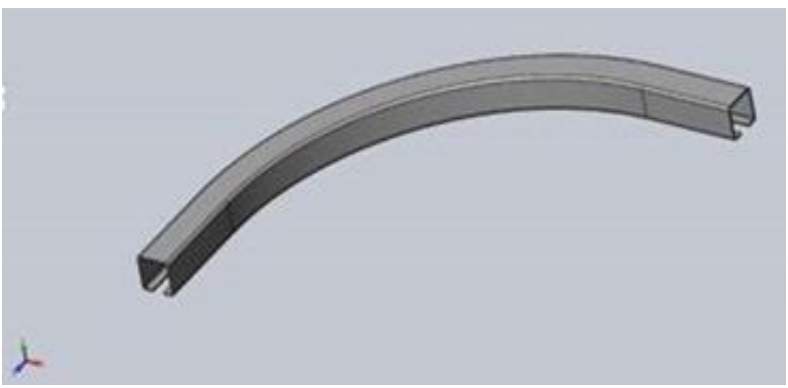

Gambar 12. Railing kurvatur 0,6 meter.

\section{HASIL DAN PEMBAHASAN}

Pada bagian ini akan dibahas hasil analisa pembebanan pada railing lurus dan railing belok dengan kurvatur 0,6 m. Melalui simulasi yang dilakukan, maka akan diperoleh nilai tegangan von mises, displacement dan safety factor atau faktor keamanan. Hasil analisa pembebanan pada railing lurus $1 \mathrm{~m}$ ditunjukkan oleh tegangan von mises pada Gambar 13. Untuk nilai displacement batang railing ditunjukkan pada Gambar 14, dan nilai safety factor ditunjukkan pada Gambar 15. Berdasarkan hasil analisa pembebanan, tegangan maksimal von mises yang terjadi sebesar 2.775 Mpa sehingga nilai safety factor sebesar 2,3 dengan tegangan maksimal material sebesar 282,7 Mpa. Adapun total displacement yang terjadi sebesar 0,018 $\mathrm{mm}$.

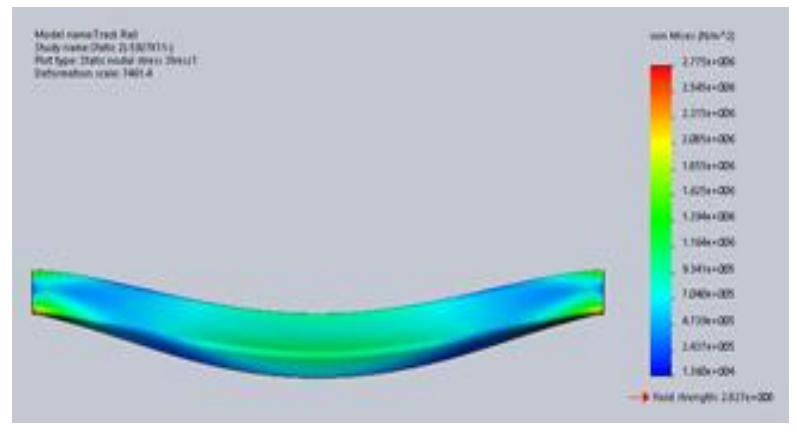

Gambar 13. Tegangan von mises batang railing $1 \mathrm{~m}$

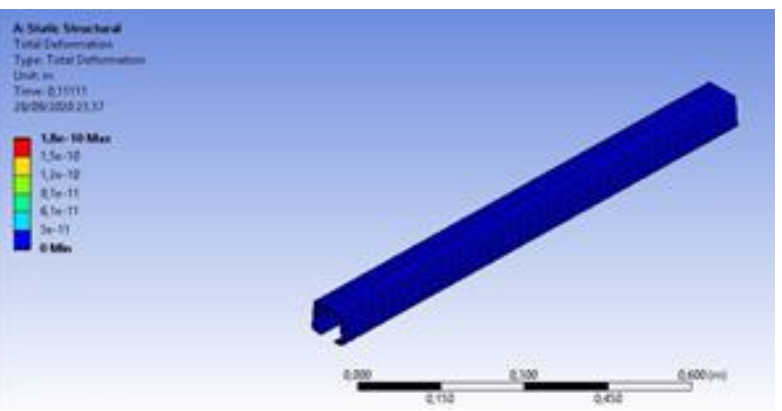

Gambar 14. Displacement batang railing $1 \mathrm{~m}$

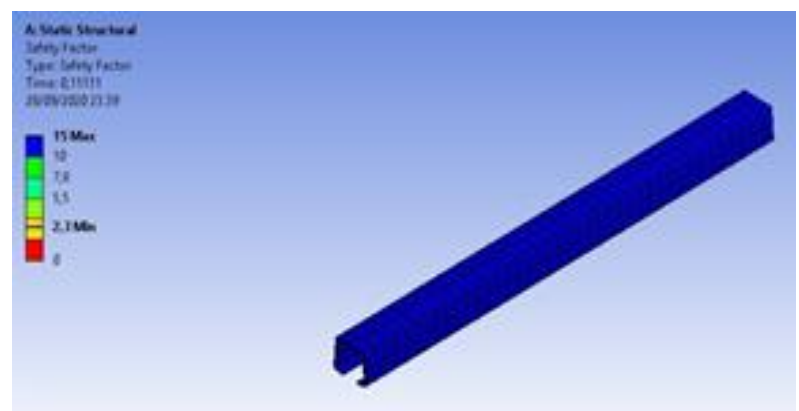

Gambar 15. Safety factor batang railing $1 \mathrm{~m}$

Selanjutnya untuk hasil simulasi komponen railing belok dengan kurvatur 0,6 $\mathrm{m}$ diperoleh hasil tegangan von mises yang ditunjukkan pada Gambar 16 , besarnya displacement yang terjadi ditunjukkan pada Gambar 17, dan nilai safety factor yang 
dihasilkan ditunjukkan pada Gambar 18. Hasil simulasi pembebanan yang sudah dilakukan pada railing belok dengan kurvatur 0,6 m menghasilkan tegangan maksimal von mises sebesar 3,91 $\mathrm{MPa}$, sehingga safety factor railing kurvatur $0,6 \mathrm{~m}$ adalah sebesar 2,45. Adapun total displacement yang terjadi sebesar $0,014 \mathrm{~mm}$.

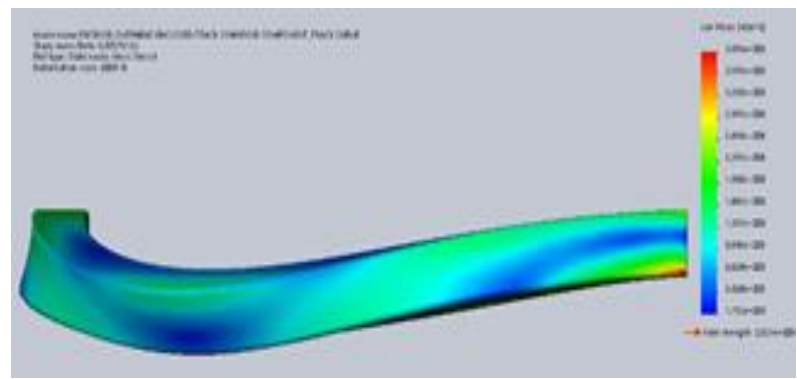

Gambar 16. Tegangan von mises railing kurvatur $0,6 \mathrm{~m}$

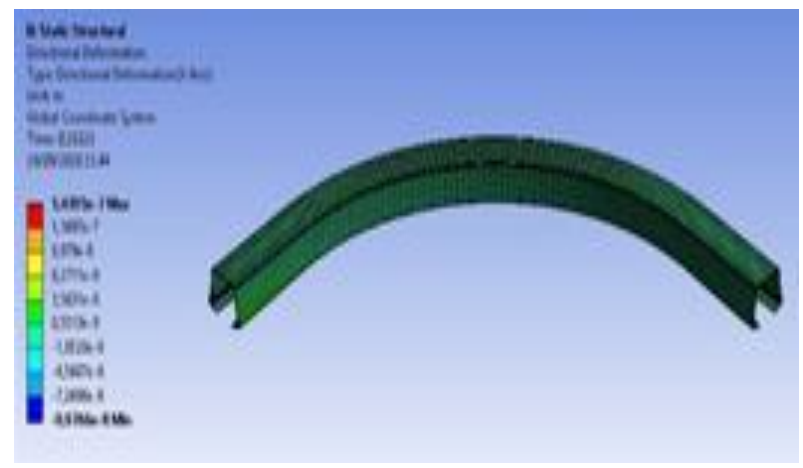

Gambar 17. Displacement railing kurvatur 0,6 m.

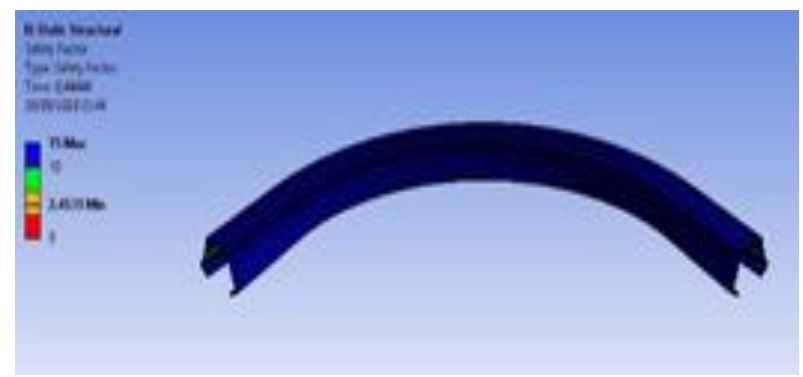

Gambar 18. Safety factor railing kurvatur $0,6 \mathrm{~m}$.

\section{KESIMPULAN}

Salah satu fungsi penambahan overhead conveyor pada kandang ayam broiler model closed house adalah untuk mengefisiensikan waktu pengangutan sekam sebagai litter dalam kendang dan pengangutan penjaringan serta panen. Berdasarkan perancangan railing overhead conveyor, maka dilakukan Analisa pemebanan pada railing lurus dengan panjang $1 \mathrm{~m}$ sebagai perwakilan railing lurus dan railing belok dengan kurvatur 0,6 m. Berdasarkan hasil simulai pada railing lurus $1 \mathrm{~m}$ dihasilkan tegangan maksimal von mises yang sebesar 2,775 Mpa dimana nilai safety factornya adalah 2,3 untuk tegangan maksimal material sebesar 282,7 Mpa. Adapun nilai displacement sebesar $0,018 \mathrm{~mm}$.
Sementara itu, simulasi komponen railing belok dengan kurvatur 0,6 memberikan hasil tegangan maksimal von mises sebesar 3,91 $\mathrm{MPa}$ sehingga safety factor sebesar 2,45 serta total displacement sebesar 0,014 mm. Berdasarakn kedua simulasi yang dilakukan menunjukkan bahwa desain overhead conveyor cukup aman dan akan segera dibuat prototipe.

\section{DAFTAR PUSTAKA}

[1]. Alimudin. 2012. Sistem Supervisori Kendali Lingkungan pada Model Broiler Closed House. Disertasi. Institut Pertanian Bogor.

[2]. Nurhadi, M. I., Siregar, S., Hendrarini, N. 2015. Desain Mekanik Sistem Pemilah Sampah. eProceeding of Applied Science. Vol. 1 No. 3 pp. 2276.

[3]. Prabowo, D.M. 2018. Analisis Pengaruh Kecepatan dan Massa Beban pada Conveyor Belt Terhadap Kualitas Pengemasan dan Kebutuhan Daya dan Arus Listrik di Bagian Produksi PT. Indopintan Sukses Mandiri Semarang. Semarang. Universitas Muhammadiyah Semarang.

[4]. Fikri, A.A., Endryansyah. 2019. Sistem Pengaturan PID Motor DC sebagai Penggerak Mini Conveyor Berbasis MATLAB. Jurnal Teknik Elektro. Vol. 8 No. 2.

[5]. Marlina, N., Zubaidah, E., Sutrisno, A. 2015. Pengaruh Pemberian Antibiotika saat Budidaya terhadap Keberadaan Residu pada Daging dan Hati Ayam Pedaging dari Peternak Rakyat. Jurnal Ilmu-Ilmu Peternakan. Vol. 25 No. 2 pp. $10-19$.

[6]. Setiawati, T., Afnan, R., Ulupi, N. 2016. Performa Produksi dan Kualitas Telur Ayam Petelur pada Sistem Litter dan Cage dengan Suhu Kandang Berbeda. Jurnal Ilmu Produksi dan Teknologi Hasil Peternakan. Vol. 4 No. 1.

[7]. Muharlien, Achmanu, Rachmawati, R. 2011. Meningkatkan Produksi Ayam Pedaging Melalui Pengaturan Proporsi Sekam, Pasir dan Kapur sebagai Litter. Ternak Tropika. Vol. 12 No. 1.

[8]. Erinofiardi. 2012. Analisa Kerja Belt Conveyor 5857-V Kapasitas 600 Ton/Jam. Jurnal Rekayasa Mesin. Vol. 3 No. 3 pp. $450-458$.

[9]. Aylak, B.L., Alias, C., Hendrikse, H.C.N., Noche, B. 2015. Necessary Calculations of Ultra-Light Overhead Conveyor Systems for InHouse Transportation. IEEE.

[10]. Aosoby, R., Rusianto, T., Waluyo, J. 2016. Perancangan Belt Conveyor sebagai Pengangkut Batubara dengan Kapasitas 2700 Ton/Jam. Jurnal Teknik Mesin. Vol. 3 No. 1 pp. $45-51$.

[11]. Fonseca, D.J., Uppal, G., Greene, T.J. 2004. A Knowledge-Based System for Conveyor Equipment Selection. Expert System with Applications. Vol. 26 Issue 4 pp. $615-623$. 
[12]. Prakosa, S., Rachmat, H., Atmaja, D.S.E. 2015. Perancangan User Requirement Specification (Urs) Sistem Otomasi pada Stasiun Kerja Pelayuan di PT. Perkebunan Nusantara VIII Kebun Ciater. e-Proceeding of Engineering. Vol. 2 No. 1 pp. 802.

[13]. Hendri. 2016. Peningkatan Kapasitas Overhead Conveyor di Lini Produksi Electrodeposition Studi Kasus: Di PT. XYZ. Jurnal Pasti Vol. X No. 2 pp. $208-216$.
[14]. Rantawi, A.B. 2013. Perancangan Unit Transfer (Screw Conveyor) pada Mesin Pengisi Polibag untuk Meningkatkan Efektivitas Kinerja di Bidang Pembibitan. Jurnal Citra Widya Edukasi. Vol. 5 No. 1.

[15]. Imron, A., Ruddianto, Budianto. 2017. Perancangan Kapal Pembersih Eceng Gondok di Sungai Rowo Tirto Probolinggo. Surabaya. Politeknik Perkapalan Negeri Surabaya. 